\title{
EDITORIAL DEPARTMENT.
}

\section{EDITORS AND PROPRIETORS.}

FRANK M. RUMBOLD, M.D.

II. A. GOLDSTEIN, MI.D.

ASBOCIATE EDITORS.

M. D. I.EDERMAN, M.D. New York.

W. SCHEPPEGHELI, M.D. New Orlenus.
S. SCOTT HISHOP, M.D. Chlcego.

F. B. EATON, MI.D. Snil José, Cal.

FOREIGN EOITORS. UR. J. LUNDAS GRANT,
LOIdOll.

DR. J. J. KIRK DUNCANSON, Edinburgh.

vR. J. K. KIMURA, Toklo.

1)IR. FIREDRICK SEMELEDER, Vern Cruz. Dr. VICTOR UIRBAN'TSCHITSCH,

DR. MARCEL NATIER, France.

DR. G. STERLING RTERSON, 'Ioronto.

DR. GOTTLIEB IICER, Copenhagen.

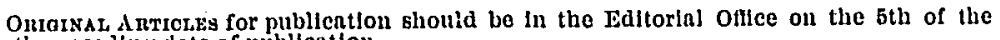
month preceding date of publication.

linuspiumos necessary to elucidate the text will be furnished, wlthout expense to authors, when suitnble ink drawings or photographs nre furnislied.

Sunsoniptiox price, $\$ 2.00$ per annum In advance. Forelgn countries, within the Postal Union, $\$ 2.95$.

CoNtriutrols to TuE Lanrwaoscope who desire reprints will plense communlcate with the Commercial Printing Company, 318 . Third Street, St. Louls, No., stating the number they wish, at the same time that they forward the arss, to the Editors.

Cossuniostrons and all drafts and money orders should be nddressed to

'IIIE LARY TOSCOPE

P. $0.130 \times 78 \pi$, St. Louls.

\section{EDITORIAL.}

\section{THE ANNUAL MEETINGS OF THE TWO NATIONAL ASSO- CIATIONS OF LARYNGOLOGISTS AT WASHINGTON.}

The American Laryngological, Rhinological and Otological Society and the American Laryngological Association beld their annual meetings at Washington the first week of May. The proceedings of these two societies at the same place, and at about the same time, proved very convenient, as a number of specialists are members of both organizations, and it enabled the members generally to follow the proceedings of both societies. 
It was somewhat unfortunate that the Section on Ophthalmology and Otology held its meeting at the same time as the Section on Laryngology. Ophthalmology and Otology are two distinct specialties, and, where the otologist desires to take in another branch, he will select. the nose and throat as most intimately associated with the ear, and not the eye. It is therefore to be hoped that the vote of the aurists at the next meeting will be suffliently strong to dis-nssociate these two branches; and, if the otologists have not enough members for a distinct organization, they should coalesce with the Section on Laryngology.

While it cannot be said that either of the two meetings have been in any degree an epoch-making one, still many interesting papers were rend, and the discussions, on the whole, were interesting.

The American Laryngological, Rhinological and Otological Society especially has our sincere congratulations on the complete success of its meeting. Althongh practically only the second annual meeting, its proceedings were of such a character that they would be a credit to any society, even of the most mature experience.

Among the subjects that were presented before the meeting of this society that were of special interest was that of Laryngectomy in Malignant Tumors, this subject being brought up by papers read by Dis. Chas. W. Richardson and Frank Hyatt, both of Washington, D.C. The majority of the opinions expressed was that, except in the very enrly strge of malignant growths in the larynx, the results of radical operations are so discouraging as not to be recommended. A minority opinion, however, held that it were better to take the very small chance of stccess of a radical operation than to suffer the lingering and pain. ful death from the ordinary course of the clisease.

The exhibition of geometric figures produced by the tones of the human voice was given by Dr. H. Holbrook Curtis of New York, and proved very instructive, as also his article on "Singer's' Nodules."

The subject of middle-enr disease was discussed at length, the subject being introduced by the papers of Drs. Edward B. Dench of New York and S. MacCuen Smith of Philaclelphia.

Malignant Transformation of Papilloma of the Larynx was described by Dr. M. R. Ward of Pittsburg, and the discussion evolsed the opinion that, while this transformation is rare, it may uncloubtedly occur. A strong argument against this opinion was made, however, as showing that the transformation is only apparent, being due to the difficulty of making a correct histological examination in these cases.

The development of the subject of the X-Rays in Disenses of the Ear, Nose and Thront was described by Dr. W. Scheppegrell of New 
Orleans, who also explained his method of treating disenses of the ac-cessory sinuses and ear by ozone gas.

The subject of ".Otitic Brain Disease" was introduced by Dr. C. A. Thigpen of Montgomery, Ala., and commanded the earnest attention of the members. His cases illustrated the advantage of operative procedures in cases in which the cranial cavity is involved.

All the subjects were thoroughly discussed, and the four sessions of the Society proved both interesting and instructive.

The election of Dr. W. H. Daly of Pittsburg was unanimously made, and the popularity and reputation of the newly-elected presi. clent will, undoubtedly, contribute to further the prosperity of the Society.

The meeting of the American Laryngological Association was somewhat disappointing in some respects. To an association which has among its members many of the most prominent laryngologists in America, and whose age and experience should give it especial advantage, we naturally look for conspicuous results, which can scarcely be said of the meeting which has just been completed. Many of the papers, Lowever, were of considerable interest. Among those may be mentioned that of Dr. J. H. Bryan of Washington, who called attention to the fact that the anterior ethmoidal cells are frequently involved in - suppurative inflammation of the frontal sinus, and that the drainge of this cavity should include that of these cells in order to obtain the most satisfactory results.

Dr. Emil Mayer of New York read an interesting paper on "Pri. mary Lupus of the Laryux," and in the discussion he supported his opinion that, while histologioally lupus of the larynx may be identical with laryngeal tuberculosis, its course, prognosis and treatment suffce to make it a clinical entity.

Dr. J. Wright introduced a paper on "Bacteria of the Normal Nose and Bacteritidal Properties of Nasal Mucus," in which, contrary to the opinion of prominent bacteriologists, he claims that pathogenic microbes may exist in the normal nose, and that the. nasal mucus does not possess bactericidal properties. This interesting paper received no discussion.

The general discussion of the meeting was on Atroplic Rhinitis, but did not develop any new facts. Dr. W. E. Casselberry of Chicago described the usual nature and symptoms of the disease, and Dr. J. Nolun Mackenzie of Baltimore, in referring to the pathology of the -disease, stated his opinion, supported by microscopic sections, that it was a later stage of hypertrophic rhinitis, as already advocated by Zuckerkandl and others. His argument in explaining the common oc- 
currence of this disease in infancy, wherens hypertrophic rhinitis is exceedingly rare, cannot be said to be tenable. No new light was thrown on the treatment of this disease, the argument being in favor of non-irritating antiseptic washes and olenginous sprays.

A paper was read by Dr. D. Bryson Delavan of New York describing a case in which a number of pathologists lad reported sarcoma, which Dr. Eugene Hodenpyl, the well-known pathologist, declared to be non-malignant, an opinion corroborated by subsequent developments, and which saved the patient from the dangers of a radical operation in this region.

Dr. Thos. R. French of Brooklyn was elected president, and his election is a compliment to the high ability and reputution of this well-known laryngologist.

W. SoHeppegrelL.

\section{A Bean in the Left Bronchus of a Child; The Appreciation of the Clinical Symptoms Furnished by the Foreign Body in the Upper Respiratory Passages.}

Dr. Koch reports the following case: $A$ boy of 9 years held a large bean in his mouth; an attack of suffocation suddenly developed, and at the same time the bean disappeared (Ann. des. Mral. de l' Or., du Larynx, etc., Oct., 1896). The dyspnœa censed at the end of a few minutes, and the child recovered its usual spirits. On the evening of the following day, however, there was fever and oppression. On the third day after the accident, the left half of the thorax showed a diminished respiratory movement and the absence of the resicular murmur. In the evening there was a second attack of suffocation, during which the foreign body was heard to strike against the larynx, producing a rustling sound. By placing the finger upon the trachea, the beating produced by the ascending and descending movements of the bean could be felt. On the seventh day the parents decided to permit tracheotomy, by means of which the forcign body was easily obtained. The recovery was prompt.

Contrary to what usually happens, the foreign body had penetrated into the left bronchus instead of the right, which is the larger and more in line with the trachen. The bean appeared a little swollen, but in spite of its having remained for a week in the respiratory passages, it had not altered and had not produced septic infection.

The brilliant result from tracheotomy in this case shows the importance of this operative measure instead of the dangerous method of expectation in the hope that the foreign body will be spontaneously expelled. TV. S. 